International Journal of Current Micro6iology and Applied Sciences

ISSN: 2319-7706 Volume 9 Number 4 (2020)

Journal homepage: http://www.ijcmas.com

Original Research Article

https://doi.org/10.20546/ijcmas.2020.904.152

\title{
Evaluation of Fungicides against Macrophomina phaseolina Inciting Root Rot of Sesame
}

\author{
C. S. Karibasappa ${ }^{1^{*}}$, Bharati N. Bhat ${ }^{1}$ and S. Chander Rao ${ }^{2}$
}

${ }^{1}$ Department of Plant Pathology, College of Agriculture, Rajendranagar, Hyderabad, India

${ }^{2}$ Crop Protection Division Indian Institute of Oilseeds Research, Rajendranagar, Hyderabad, India

*Corresponding author

\section{A B S T R A C T}

\section{Keywords}

M. Phaseolina, Vitavax power, TopToo, Macrophomina phaseolina

Article Info

Accepted:

12 March 2020 Available Online: 10 April 2020
Six fungicides viz., Tebuconazole + Trifloxystrobin 75 WG (Nativo), Hexaconazole 5\% + Captan $70 \%$ WP (Taqat), Carboxin 37.5\% + Thiram $37.5 \%$ WP (Vitavax power), Iprovalicarb 5.5\% + Propineb 61.25\%WP (Melody duo), Carbendazim 50WP (Hycarb), Mancozeb 63\% W.P. + Carbendazim 12\% WP (Top too) were evaluated in vitro to test their efficacy against Macrophomina phaseolina by poisoned food technique. Results revealed that all the fungicides were effective in inhibiting mycelial growth of $M$. phaseolina to varying degrees. Complete inhibition (100\%) of growth of pathogen over control was observed in Vitavax power followed by TopToo.

\section{Introduction}

Sesame (Sesamum indicum L.) have been cultivated since from 2350 B.C. for edible oil and food (Robbelen, 1989). It is regarded as the 'Queen of Oilseeds', the quality of its oil being highly stable with high nutritional and therapeutic value. It is an excellent source of vegetable oil and contains oil (43.4-58.8\%), sugar (14-16\%), protein (20-28\%), and minerals $(5-7 \%)$. Its seeds are rich source of food, edible oil, nutrition and have uses in health care also; the oil is quite stable due to the presence of antioxidants such as sesamin, sesamolin and sesamol (Suja et al., 2004). Therefore, it is used to blend with other less stable vegetable oils to increase their stability and longevity (Chung and Choe, 2004).

Due to the presence of antioxidants and low level of saturated fatty acids, sesame oil reduces the incidence of hypertension and lowers the cholesterol level in human beings (Lemcke Norojarvi et al., 2001; Sankar et al., 
2004). Wherever sesame is grown, it is liable to infected by various pathogenic fungi (AbdEl-Ghany et al., 1974). Among these fungal diseases, charcoal rot/root rot of sesame caused by M. phaseolina is the most devastating disease (Dinakaran and Manoharan 2001) M. phaseolina is a facultative parasite which survives in the soil and in crop residues as sclerotia and it has also been reported to be seed-borne (Verma et al., 2002). Sesame plants infected by this pathogen exhibits varied symptoms like seed rot, seedling decay, stem as well as root rot (Kolte, 1985; Verma et al., 2005).

In India it is reported to be occurrence of about $50 \%$ diseases incidence which results in heavy yield losses (Chattopadhyay and Kalpna, 2002). At present chemical fungicides are the primary option with the farmers to combat diseases because of their easy adaptability and immediate therapy. The main objective of this study was to evaluate the six different fungicides at two different concentrations for testing their efficacy against mycelial growth inhibition of Macrophomina phaseolina under in vitro conditions.

\section{Materials and Methods}

In vitro evaluation of fungicides, botanicals and biocontrol agents

In vitro screening of fungicides against $M$. phaseolina

The following fungicides mentioned below in Table 1 were evaluated against $M$. phaseolina under in vitro conditions by poisoned food technique (Vincent, 1927) at two concentrations i.e. recommended and half the recommended dose. Three replications were maintained for each treatment with control. Six fungicides viz., Tebuconazole + Trifloxystrobin 75 WG (Nativo),
Hexaconazole 5\% + Captan $70 \%$ WP (Taqat), Carboxin 37.5\% + Thiram 37.5\% WP (Vitavax power), Iprovalicarb $5.5 \%+$ Propineb 61.25\%WP (Melody duo), Carbendazim 50WP (Hycarb), Mancozeb 63\% W.P. + Carbendazim 12\% WP (Top too) at recommended, and half-recommended dosages were evaluated separately against root rot pathogen, M. phaseolina under in vitro conditions by poisoned food technique (Vincent, 1927).

For each treatment, $100 \mathrm{ml}$ of potato dextrose agar was taken in $250 \mathrm{ml}$ conical flask and sterilized in an autoclave. Fungicide was added to the sterilized medium at lukewarm temperature under aseptic conditions and mixed thoroughly by shaking to obtain the above mentioned concentrations. The poisoned medium was equally distributed in the Petri plates and allowed to solidify.

Three replications were maintained for each treatment. Discs of $5 \mathrm{~mm}$ diameter of the actively growing test fungal cultures were cut with sterilized cork borer separately and transferred to the centre of the poisoned medium in each of the Petri plates. Similarly, control was maintained by placing $5 \mathrm{~mm}$ discs of test fungal culture in centre of the plates containing the medium without fungicide. All the Petri plates were incubated at $28 \pm 1^{\circ} \mathrm{C}$ in BOD incubator.

The diameter of fungal colony was measured in each of the treatment when the pathogen growth in control plate was full. The colony diameter inhibited in fungicide treated plates as compared to control was taken as a measure of fungi toxicity. Per cent inhibition over control was calculated by following the equation (Vincent, 1927):

$$
\mathrm{I}=\frac{\mathrm{C}-\mathrm{T}}{\mathrm{C}} \times 100
$$

Where, 
$\mathrm{I}=$ Per cent inhibition over control

$\mathrm{C}=$ Radial growth of pathogen in control (mm)

$\mathrm{T}=$ Radial growth of pathogen in treatment (mm)

\section{Results and Discussion}

In vitro evaluation of fungicides, botanicals and biocontrol agents

In vitro screening of fungicides against $M$. phaseolina

The efficacy of six fungicides was tested in vitro by poisoned food technique and the results are presented in Table 2 and Plate 1. All the fungicides were effective in inhibiting radial growth of $M$. phaseolinato varying degrees. Significant difference was observed among the fungicides except two fungicides Vitavax power and Toptoo which were found to be on par with each other in inhibiting the mycelial growth of the pathogen.

Complete inhibition (100\%) of growth of pathogen over control was observed in Vitavax power treatment at 2000ppm (Table 2 and Figure 1). This was followed by Top too $(98.79 \%)$, In the order of merit other fungicides found inhibitory were carbendazim (97.59\%), Nativo (94.23\%) and Taqat $(66.38 \%)$. Melody duowas least effective (28.45\%) at both (1000ppm and 2000ppm) the concentrations in inhibiting the growth of the pathogen.

Table.1 Details of the fungicides used in bioassay studies under in vitro condition against $M$. phaseolina

\begin{tabular}{|c|c|c|c|c|}
\hline Sl. No. & Common name & $\begin{array}{l}\text { Trade } \\
\text { name }\end{array}$ & $\begin{array}{l}\text { Treatment } \\
\text { number }\end{array}$ & $\begin{array}{c}\text { Dosage } \\
\text { (ppm) }\end{array}$ \\
\hline \multirow[t]{2}{*}{1} & \multirow{2}{*}{$\begin{array}{l}\text { Tebuconazole + Trifloxystrobin } 75 \\
\text { WG }\end{array}$} & \multirow[t]{2}{*}{ Nativo } & $\mathrm{T}_{1}$ & 2000 \\
\hline & & & $\mathrm{T}_{2}$ & 1000 \\
\hline \multirow[t]{2}{*}{2} & \multirow[t]{2}{*}{ Hexaconazole $5 \%$ + Captan70\% WP } & \multirow[t]{2}{*}{ Taqat } & $\mathrm{T}_{3}$ & 2000 \\
\hline & & & $\mathrm{T}_{4}$ & 1000 \\
\hline \multirow[t]{2}{*}{3} & \multirow[t]{2}{*}{ Carboxin $37.5 \%$ + Thiram $37.5 \% \mathrm{WP}$} & \multirow{2}{*}{$\begin{array}{l}\text { Vitavax } \\
\text { power }\end{array}$} & $\mathrm{T}_{5}$ & 2000 \\
\hline & & & $\mathrm{T}_{6}$ & 1000 \\
\hline \multirow[t]{2}{*}{4} & \multirow{2}{*}{$\begin{array}{l}\text { Iprovalicarb } 5.5 \%+\text { Propineb } \\
61.25 \% \mathrm{WP}\end{array}$} & \multirow[t]{2}{*}{ Melody duo } & $\mathrm{T}_{7}$ & 2000 \\
\hline & & & $\mathrm{T}_{8}$ & 1000 \\
\hline \multirow[t]{2}{*}{5} & \multirow[t]{2}{*}{ Carbendazim 50WP } & \multirow[t]{2}{*}{ Hycarb } & $\mathrm{T}_{9}$ & 2000 \\
\hline & & & $\mathrm{T}_{10}$ & 1000 \\
\hline \multirow[t]{2}{*}{6} & \multirow{2}{*}{$\begin{array}{l}\text { Mancozeb } 63 \% \text { W.P. + Carbendazim } \\
12 \% \text { WP }\end{array}$} & \multirow[t]{2}{*}{ Top too } & $\mathrm{T}_{11}$ & 2000 \\
\hline & & & $\mathrm{T}_{12}$ & 1000 \\
\hline
\end{tabular}


Table.2 Effect of fungicides on the mycelial growth of Macrophomina phaseolina under in vitro conditions

\begin{tabular}{|c|c|c|c|c|c|c|c|c|c|}
\hline Sl No. & Fungicide & $\begin{array}{l}\text { Recommended } \\
\text { concentration } \\
(\text { ppm })\end{array}$ & $\begin{array}{c}\text { Treatment } \\
\text { number }\end{array}$ & $\begin{array}{l}\text { Linear } \\
\text { mycelial } \\
\text { (mm) } \\
\text { growth }\end{array}$ & $\begin{array}{c}\text { Inhibition of } \\
\text { Macrophomina } \\
\text { phaseolinaover } \\
\text { control }(\%)\end{array}$ & $\begin{array}{c}\text { Half the } \\
\text { Recommended } \\
\text { concentration } \\
\text { (ppm) }\end{array}$ & $\begin{array}{c}\text { Treatment } \\
\text { number }\end{array}$ & $\begin{array}{l}\text { Linear } \\
\text { mycelial } \\
\text { growth } \\
(\mathrm{mm})\end{array}$ & $\begin{array}{c}\text { Inhibition of } \\
\text { Macrophomina } \\
\text { phaseolinaover } \\
\text { control }(\%)\end{array}$ \\
\hline 1 & $\begin{array}{c}\text { Tebuconazole } \\
+ \\
\text { Trifloxystrobin } \\
75 \mathrm{WG}\end{array}$ & 2000 & $\mathrm{~T} 1$ & $5.19^{*}$ & 94.23 & 1000 & $\mathrm{~T} 2$ & $6.05^{a}$ & 93.27 \\
\hline 2 & $\begin{array}{c}\text { Hexaconazole } 5 \\
\%+ \\
\text { Captan } 70 \% \\
\text { WP }\end{array}$ & 2000 & $\mathrm{~T} 3$ & 30.25 & 66.38 & 1000 & $\mathrm{~T} 4$ & 34.14 & 62.06 \\
\hline 3 & $\begin{array}{c}\text { Carboxin } \\
37.5 \%+ \\
\text { Thiram } 37.5 \%\end{array}$ & 2000 & $\mathrm{~T} 5$ & 0.00 & 100 & 1000 & $\mathrm{~T} 6$ & 1.09 & 98.79 \\
\hline 4 & $\begin{array}{c}\text { Iprovalicarb } \\
5.5 \%+ \\
\text { Propineb } \\
61.25 \% \mathrm{WP}\end{array}$ & 2000 & $\mathrm{~T} 7$ & 64.39 & 28.45 & 1000 & $\mathrm{~T} 8$ & 73.36 & 18.48 \\
\hline 5 & $\begin{array}{l}\text { Carbendazim } \\
\text { 50WP }\end{array}$ & 2000 & $\mathrm{~T} 9$ & 2.17 & 97.59 & 1000 & $\mathrm{~T} 10$ & 5.51 & 93.87 \\
\hline 6 & $\begin{array}{c}\text { Mancozeb } \\
63 \% \text { W.P. + } \\
\text { Carbendazim } \\
12 \% \text { WP }\end{array}$ & 2000 & $\mathrm{~T} 11$ & 1.09 & 98.79 & 1000 & $\mathrm{~T} 12$ & 2.17 & 97.59 \\
\hline 7 & Control & ----- & & 90.00 & & & & 90.00 & \\
\hline & \multicolumn{2}{|c|}{$\mathrm{CD}(\mathrm{p}=0.05)$} & & 1.23 & & & & 1.33 & 1.79 \\
\hline & \multicolumn{2}{|c|}{$\mathrm{SE}(\mathrm{m}) \pm$} & & 0.40 & & & & 0.43 & 0.58 \\
\hline & \multicolumn{2}{|c|}{$\mathrm{CV}(\%)$} & & 2.51 & & & & 2.47 & 1.29 \\
\hline
\end{tabular}




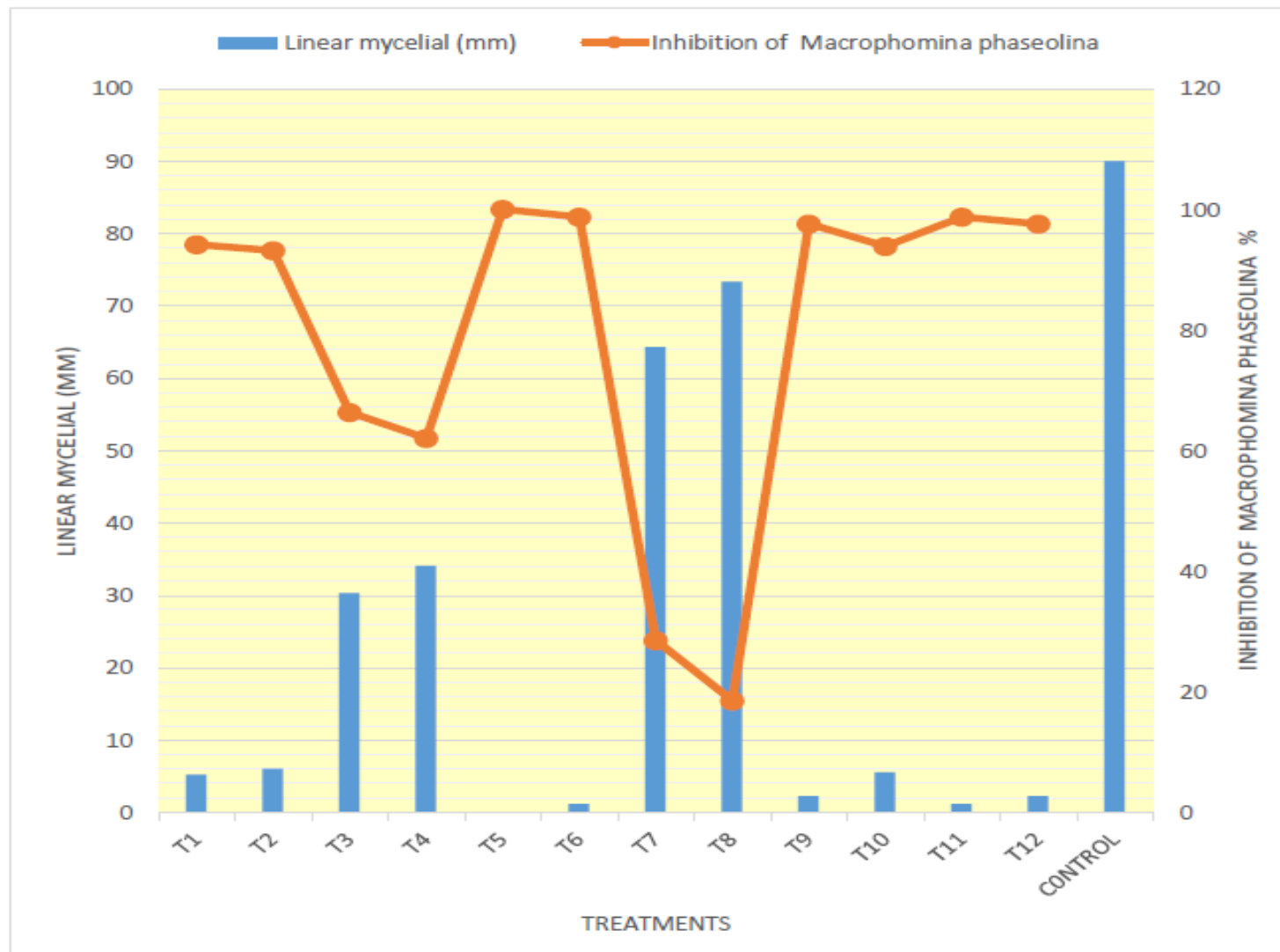

Figure.1 Effect of fungicides on the mycelial growth of Macrophomina Phaseolina under in vitro conditions

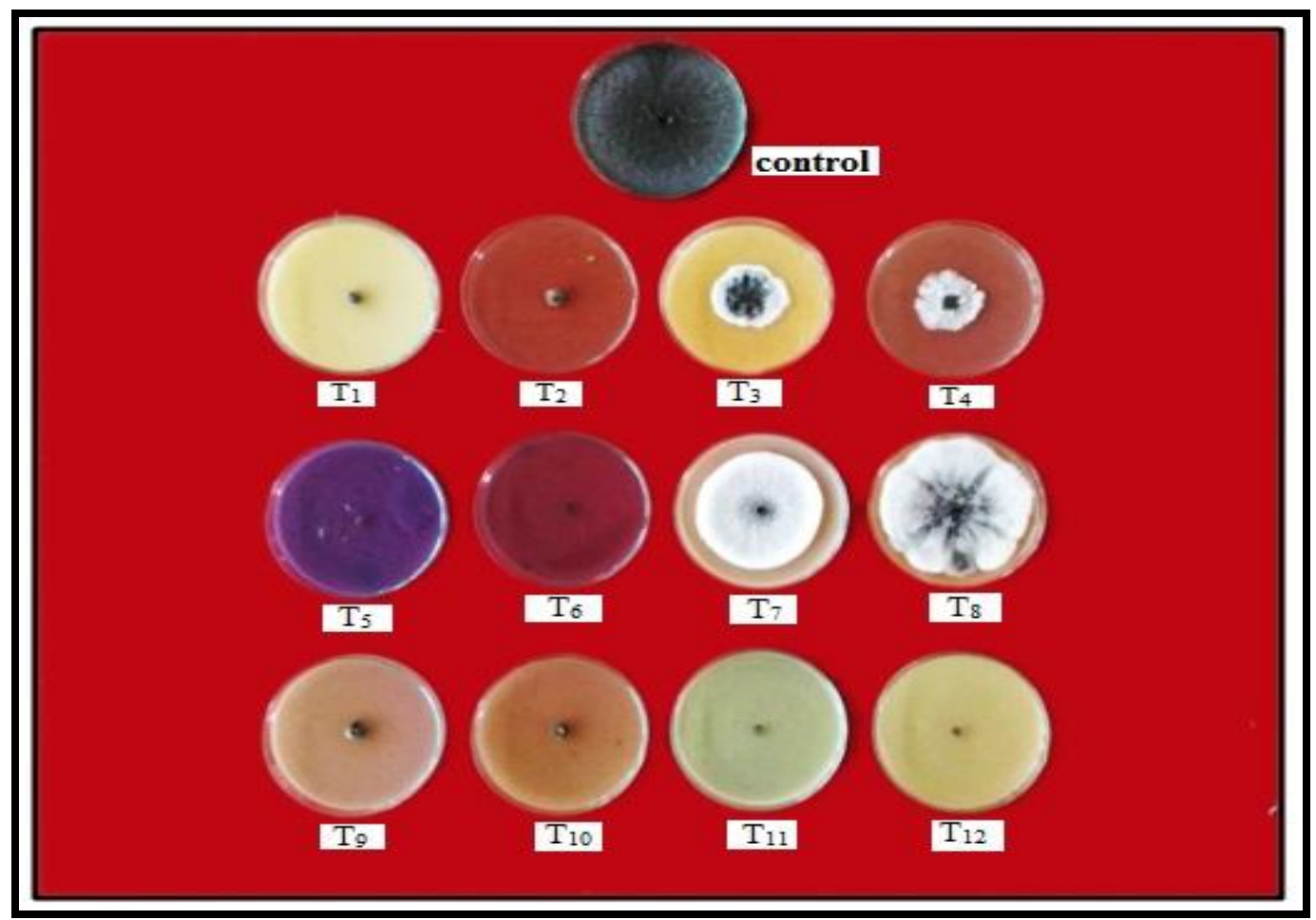

Plate.1 In vitro evaluation of fungicides against M. phaseolina 
Similar results were obtained by Deepthi et al., (2014) who reported that Vitavax power and Penflufen gave $100 \%$ inhibition of mycelial growth of $M$. phaseolina and the field evaluation of different fungicides indicated that Vitavax power gave highest sesame seed germination $(85.10 \%)$ and less pre and post emergence mortality (14.88\% and $27.66 \%$ ), and yield loss (32.09\%) against M. phaseolina.

Suryawanshi et al., (2008)observed that fungicides carbendazim $(0.1 \%)$, mancozeb $(0.2 \%)$ and thiram $(0.3 \%)$ caused highest inhibition $(94.18 \%)$ and were at par with each other. This was followed by thiophanate methyl (93.56\%) against $M$. phaseolina inmungbean. Choudhary et al., (2014)also reported that seed treatment with carbendazim $50 \mathrm{WP}(0.15 \%)+$ thiram $(0.15 \%)$ recorded minimum disease incidence of Macrophomina root rot in sesame with $11.15 \%$ and $9.91 \%$ followed by carbendazim 50WP (23.06\% and $21.01 \%)$.

\section{References}

Abd-El-Ghany, A. K., Seoud, M. B., Azab, M. W., Mahmoud, B. K., El-Alfy, K. A. A. and Abd-El-Gwad, M. A. (1974). Tests with different varieties and strains of sesame for resistance to root rot and wilt diseases. Agricultural Research Review. 52:75-83.

Chattopadhyay, C. Kalpna, S. (2002). Combining viable disease control tools for management of sesame stem root rot caused by Macrophomina phaseolina (Tassi) Goid. Indian Journal of Plant Protection. 30(2):132-138.

Choudhary, C.S., Arun, A. and Prasad, S.M. (2014).Management of stem and root rot of sesame. International Journal of Agricultural Sciences. 10(2): 755-760.

Chung, J. L. and Choe, E. (2004). Oxidative stability of soybean and sesame oil mixture during frying of flour dough. Journal of Food Science. 69: 574-578.

Deepthi, P., Shukla, C.S., Verma, K.P. and Siva Sankar Reddy, E. (2014). Identification of charcoal rot resistant lines of Sesamum indicum and chemical management of Macrophomina phaseolina. Medicinal Plants. 6(1): 3642.

Dinakaran, D. and Manoharan, N. (2001). Identification of resistant sources to root rot of sesame caused by Macrophomina phaseolina (Tassi.) Goid. Sesame Safflower Newsletter. 16:68-71.

Javed, M.S., Wahid, A. and Idress, M. (1995). Fungi associated with sesame seeds and their frequency. Pakistan Journal of Phytopathology. 7(2): 174-176.

Jeyalakshmi, C., Rettinassababady, C. andNema, S. (2013). Integrated management of sesame diseases. Journal of Biopesticides.6(1): 68-70.

Kolte, S.J. (1985). Diseases of Annual Edible Oilseed Crops Vol. II. RapeseedMustard and Sesame Diseases. CRC Press Inc. Boca Raton Florida, USA. 83-112.

Kolte, S. J. (1985). Diseases of Annual Edible Oilseed Crops Vol. II. RapeseedMustard and Sesame Diseases. CRC Press Inc. Boca Raton Florida, USA. 83-112.

Lemcke-Norojarvi, M., Kamal-Eldin, A., Appelqvist, L. A., Dimberg, M. O. and Vessby, B. (2001). Corn and sesame oils increase serum gamma-tocopherol concentrations in healthy Swedish women. Journal of Nutrition. 131:11951201.

Robbelen, G., Downey, R. K. and Ashri, A. (Eds.). (1989), Oil Crops of the World, McGraw-Hill, New York. pp. 375-387.

Sankar, D., Rao, S. M. R. and Pugalendi, K. V. (2004) Impact of sesame oil on nifedipine in modulating oxidative 
stress and electrolytes in hypertensive patients. Asia Pacific journal of clinical nutrition. 13:107.

Suja, K. P., Abraham Thamizh, S. N., Jayalekshmy, A. and Arumughan, C. (2004). Antioxidant efficacy of sesame cake extract in vegetable oil protection. Food Chemistry. 84:393-400.

Suryawanshi, V.P., Hajare, S.T., Karnewar, S.D., Kamble, N.S., Dhawle, R.N. and Digraskar, O.S. (2008). Isolation, identification and pathogenicity of Macrophomina phaseolina with special reference to blackgram. Journal of Soils and Crops.18(1): 143-146.

Verma, M.L., Mehta, N. andSangwan, M.S. (2005). Fungal and bacterial diseases of sesame In Diseases of Oil seed Crops. Indus Publishing Company, New Delhi. 634.

Verma, M. L., Mehta, N. and Sangwan, M. S. (2005). Fungal and bacterial diseases of sesame In Diseases of Oil seed Crops. Indus Publishing Company, New Delhi. 634.

Verma, M.L., Prasad, D. and Puri, S.N. (2002).Fungal and bacterial diseases of sesame and their management. Crop Pest and Disease management: Challenges for the millennium. Jyoti Publishers \& Distributors. Dehra Dun, India: 161-192.

Verma, M. L., Prasad, D. and Puri, S. N. (2002).Fungal and bacterial diseases of sesame and their management. Crop Pest and Disease management: Challenges for the millennium. Jyoti Publishers \& Distributors. Dehra Dun, India: 161-192.

Vincent, J.M. (1927). Distortion of fungal hypae in the presence of certain inhibitors. Nature. 159: 850.

\section{How to cite this article:}

Karibasappa, C. S., Bharati N. Bhat and Chander Rao, S. 2020. Evaluation of Fungicides against Macrophomina Phaseolina Inciting Root Rot of Sesame. Int.J.Curr.Microbiol.App.Sci. 9(04): 1293-1299. doi: https://doi.org/10.20546/ijcmas.2020.904.152 